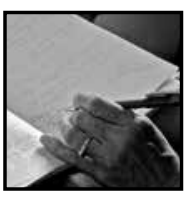

\title{
To Where Teachers Learn: Following the Yellow Brick Road
}

\author{
The Narrative Inquiry Group
}

\section{ABSTRACT}

This article describes the journey of The Narrative Inquiry Group, a community of high school educators engaged in embedded, self-directed professional development. Our approaches include professional conversation, narrative inquiry, and literary métissage, and our results consist of productions representative of our selves, learning, and practices. We would suggest that our inquiries map the path of individual and collective experience, and illustrate the value of being self-critical within the safety of a learning community. In addition, we hope to inform others' research and practice, and those with an interest in teacher education, of the importance of understanding the experience of educators engaging in inquiry.

From the far north they heard a low wail of the wind, and Uncle Henry and Dorothy could see where the long grass bowed in waves before the coming storm. There now came a sharp whistling in the air from the south, and as they turned their eyes that way they saw ripples in the grass coming from that direction also. Suddenly, Uncle Henry stood up. "There's a cyclone coming, Em," he called to his wife.

- L. Frank Baum, The Wonderful Wizard of Oz (1939, p. 2)

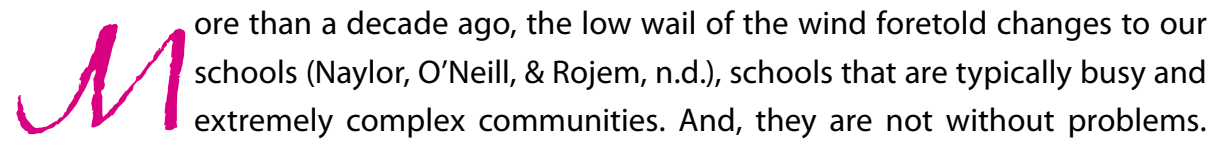

We have faced political, social, and professional shifts; reinvented policies and working conditions; reconceptualized pedagogies, and demands for best practice (Kamanzi, Riopel, \& Lessard, 2007). Curriculum content, delivery, evaluation, and reporting have changed. We work harder for longer hours, greet complex student groups, learn 
and teach evolving technologies, and do more administrative work and paperwork. Learners arrive with advanced knowledge of technologies, and represent a mosaic of languages, ethnicities, and cultures; of learning abilities, needs, gifts and talents; of problems of motivation, apathy, bullying, absenteeism, and family issues. Challenges, as do storm clouds, evolve and gather momentum, yet planned time for self-directed, long-term professional development and collaboration is as scarce as a rain cloud once was in Uncle Henry's Kansas sky.

Like Dorothy, in The Wonderful Wizard of $\mathrm{Oz}$, each of us has experienced cyclonic conditions in our schools at one time or another. The strain of balancing work and life beyond, leaves us feeling as though tossed out of a wind tunnel-wide-eyed, breathless, bruised, sometimes lost. However, in our work we face our problems head-on, and our inquiries sustain our problem-solving endeavours. We support each other's selfdirected initiatives, participating in voluntary, embedded professional development.

Within The Narrative Inquiry Group, there exists a strong sense of professional purpose, and we have chosen to skip quick fixes, opting rather to invest in the long term. Our conversations focus on a variety of issues, problems, and possible solutions through a range of inquiry processes. Guidelines for these are found under the umbrella of action research (Holly, Arhar, \& Kasten, 2001), and within the professional conversation (Rust, 2002), narrative inquiry (Clandinin, \& Connelly, 2000), and literary métissage (Hasebe-Ludt, Chambers, \& Leggo, 2009, Chambers, Hasebe-Ludt, Leggo, \& Sinner, 2012) perspectives. In this paper we will discuss some of the outcomes of one phase of our research, The Blackboard Monologues, which may provide evidence of our learning from experience. What follows is a descriptive overview of our work.

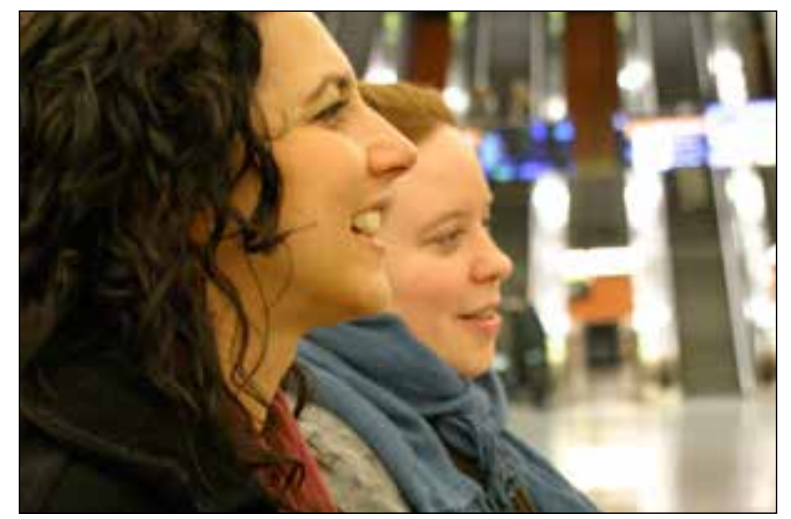

Fig. 1: Métissage: The blackboard monologues

Press here for performance 


\section{Our Learning in a Broader Context: We Are Not in Kansas Anymore}

The function of reflective thought is ... to transform a situation in which there is experienced obscurity, doubt, conflict, disturbance of some sort into a situation that is clear, coherent, settled, harmonious.

- John Dewey, How We Think: A Restatement of Reflective Thinking to the Educative Process, 1933, p. 100

Our individual interests in stories of teaching and learning bring us together and we have enjoyed the benefit of professional conversation for a number of years now. Professional conversation (Rust, 2002) provides us with a forum for the communication of experience, insight, and knowledge. As well, it has provided us with a point of departure for collective research. Professional conversation may be defined as:

An approach to professional learning and quality improvement which values the practical knowledge and wisdom of professionals ... (who) engage in a constructive dialogue on a topic of shared interest and importance ... The process is reliant on providing participants with sufficient time and space to critically reflect, to form and share views and experiences, and to move from surface knowledge to deeper knowledge and understanding. (Irvine \& Collie, 2011, p. 4)

Inquiries emerging from our conversations adhere to the narrative tradition as understood by Clandinin and Connelly (2000). "(N)arrative inquiry is a way of understanding experience ... over time, in a place or series of places, and in social interaction with milieus ... narrative inquiry is stories lived and told" (p. 20). We use stories to make sense of and communicate experience, to challenge assumptions, to guide future actions. Our practices foster reflection, which in turn frames a story, and the story will then inform practice (Duff, 2002). Our various texts embody us and our emerging identities. We attend to them, make sense of them (Elza, 2011).

Carl Leggo (2010) offers the following: "We know ourselves only in images, written in words and light. My sense of who I am in the world is an effect of language, a sense of presence, a representation, seemingly whole, but always fragmentary" (p. 48). In our work, we are coming to know ourselves as artifacts of practice unearthed in our narratives. However, literary métissage (Hasebe-Ludt et al., 2009) takes us beyond individual reflective, autobiographical pieces, to the possibility of transforming not just our writing, but our selves and our community as well. Literary métissage is a form of life writing that explores and exposes the: 
Counter-narrative to the grand narratives of our times ... (provides) a site for writing and surviving in the interval between different cultures and language ... It is a way of merging and blurring genres, texts and identities ... Métissage requires researchers to craft pieces of autobiographical writing in which they research and teach themselves. Texts are selected and braided ... using themes which evolved organically. (p. 9)

Fragments of our individual lives are questioned, interpreted, shared, and connected. The resulting braid may appear ambiguous or familiar, as the audience is drawn into the weave (Sinner, 2010), and ought to promote understanding and empathy (Simpkins 2012).

In our work, we take theories of professional conversation, narrative inquiry, and literary métissage as an ensemble, and an epistemological tool for use in our explorations and explanations of our lives as educators. Beyond that, we believe that a theory of perspective transformation is useful in understanding the learning represented in our narratives of critical self-reflection. The transformative nature of adult learning has been widely investigated, and Jack Mezirow (2000) provides a framework for understanding our professional development. Mezirow (1991b) defines learning as a process of transformation "using a prior interpretation to construe a new or a revised interpretation of the meaning of one's experience in order to guide future action" (p. 12). Learning is the consequence of critical reflection and involves experiencing disorientation, the examination of assumptions, planning and enacting change, searching for meaning and peace, self-acceptance, and reintegration and adjustment to a new perspective (Mezirow, 1991a).

\section{Mapping Progress: Our Journey to Oz}

Walk on your own yellow brick road. If you can't find one, spray paint your way into happiness. If that doesn't work, buy yellow shoes.

- Sadiqua Hamdan, Happy am I. Holy am I. Healthy am I., 2013, p. 4

Within The Narrative Inquiry Group our task-and our pleasure-is to engage with each other in discourse on topics that range from here to $\mathrm{Oz}$ and back. And, we learn as we go. We have situated our work in the gap between the professional and the personal, (Hubbard et al., 2013), and between theory and practice (Jager et al., 2014). The process of choosing topics and direction for the group has been spontaneous. When someone puts forward an idea for a narrative, we discuss it, tweak and move forward with it. 
Such was the case with The Blackboard Monologues. Denise, a member of the group, shared her reflections on how her perspective on teaching and learning had shifted as a consequence of being on maternity leave. Kristen, likewise a member, suggested exploring monologue (Ensler, 2001) as a method of narrative inquiry. Together, we decided to develop monologues on our individual perspectives, while striving to create shared understandings of ourselves, and our thoughts on teaching and learning.

"(M)étissage requires researchers to craft pieces of autobiographical writing in which they research and teach themselves. The texts are selected and braided in such a way as to highlight both points of affinity and dissonance" (Hasebe-Ludt et al., 2009, p. 9). Our monologues on the theme of perspective were, first, analyzed for common thematic strands. Once these were identified, the individual monologues were then braided into a collective piece through consensus and conversation. What follows are introductions to some of the authors and excerpts from their contributions to the project.

\section{Norma Hubbard}

Norma teaches English and the International Baccalaureate Personal Project at Heritage Regional High School (HRHS), and holds a BEd from McGill University.

\section{Getting my hands dirty.}

There are weeds in my garden-hidden among the more desirable plants. If I stand back and look at all my gardens, it seems like a daunting task to control. There is so much to do and so little time to do it in. My classroom seems like this in the fall. If I look at all my students, the sheer number of them overwhelms me. Who are all of these children? Where do I start? ... I look around and there are dragonflies and butterflies within my garden. I love the dragonflies, they are curious and dart everywhere, only occasionally resting-dragonflies are my ADD students, my artists and dreamers. They keep me alert. The butterflies, especially the beautiful swallowtails, seem to float over the flowers, only coming to me if I remain still. These are those amazing students whom I learn so much from and yet they often credit me with teaching them-when all I did was provide the space for them to fly.

\section{Amanda Jager}

Amanda teaches English Language Arts at Chambly Academy. She holds a BEd and MA from McGill University. 
Ring.

... Teachers and students alike-we glance at our watches, we roll through that stop sign, we gulp down that last glug of coffee, we lateral pass our Timmy's cup into the trash can better than any pro-football player ever could. Whether there's a full mug of sharpened pencils on our desk or a messy stack of half-graded essays sticking out of our bag, we're all watching for the same sound-calling us to teach... We collaborate in theory... But what about today?... Work with me, for them. Because it is a messy job, a jigsaw puzzle missing piece after piece after piece. Falling through the cracks, lost in supply closets, burned out and retired and first year and new to the school and "how many more years?" and "I have some resources for that" and "how was your group today?" and "one time I" and "you must be tired" and "what do you think I should" and "thanks for your help" and "I don't know why I am crying!" and "I really shouldn't be laughing at this but..."

\section{Martin Labrie}

Martin teaches visual and performing arts at HRHS. He holds a Bachelor of Dance Education Degree from Université du Québec à Montréal.

\section{My purple day.}

Today would not be a day like any other. Today would be my Purple Day, a day I will remember for the rest of my life, a day that would change my life and my students' lives too-at least some of them ... "Mister Labrie, how come you're not wearing purple today? I thought you would be supportive" ... And Allysson told me that Purple Day was for the kids who killed themselves because of homophobia ... Allyson did not know that she opened the door-the door of my classroom to the school, and the rest of the world. Later that day, as I am in my first year in high school after 14 years in elementary, I was to have an evaluation with the VP in charge of the Arts, Ms. McCarthy. I told her that I would like to make my coming out, to tell my students that I am gay, because I want to be honest with them. And she told me the administration would be very happy and supportive if I were to do this as a role model ... I saw my Secondary V students, my 504s, my art option class entering the room, dressed in purple ... No way! Half of them, maybe more. So, I told them to follow me to the Art Depot, a small room with a large square table in the center. It looked like a walk-in closet, and I would walk out in a minute. I told them, "I am a gay teacher!" 


\section{Laurie MacLeod}

Laurie is a retired English teacher from Saint Johns High School in Saint Jean, Quebec, and holds a BEd from the University of New Brunswick and a Graduate Certificate in Special Education from McGill University.

\section{Finding the light.}

The child's soul grows

With egg-shell domes and

Cotton-ball snow as she

Imagines how people

Live in the northern cold -

And the light peeks through

The kitchen window nudging

Her mind, to wander further ...

The light shines around her

When learning is valued...

The teacher's soul

Sees this and,

Now fully awake,

Turns to her first love -

Her passion for learning ...

My heart will be lighter

If just one child

Is nudged out of the darkness,

And chooses the warmth,

Learns of the secrets,

The strength of his mind.

Learns if he chooses,

His passions, his sorrows,

That he is his own master,

That he has the power

To light up this world ...

Or live in the dark.

\section{Diane Mallet}

Diane is a special education attendant at HRHS, and a Special Education TeacherAssistant graduate of MacEwan College in Edmonton, Alberta. 


\section{Four perspectives on cracks.}

\section{I}

Am a good example of how things changed.

I fell through the cracks...

I wanted to be invisible.

I hated and feared being called upon during reading and spelling.

Boy!

I have come a long way. . .

I found the Illiteracy Connection.

It took a year before I was reading.

I felt empowered and books became my new best friend ...

I enrolled in the Special Education Teacher-Assistant Program.

I excelled, and helping special needs children became my passion ...

The only way I know how to help those with learning disabilities is to offer encouragement, support, and a never-give-up attitude.

I remember what it was like for me.

If I had had the support I give the students I work with, I could have accomplished more...

I have a dream that no student will fall through the cracks.

\section{Judith McBride}

Judy is a retired teacher with a PhD in Educational Psychology from McGill University. She volunteers as research coordinator at HRHS.

\section{The hermit crab.}

A hermit crab sidles up to me, wanting to share my shade.

I sit under a palapa, on a beach, in Mexico, mid-winter.

I can be here now, I have retired.

Once, though, I was the Hermit Crab ...

Within my shells, I have nurtured and loved other people's children.

I have taught.

Now, ever longing, never able to find my way back, I leave my shells behind.

My shells. Others have come to dwell within my shells...

Eavesdropping outside the shells of others, I listen for stories.

With knowing voices, teachers tell of their yearning and learning and loving and growing,

Stories of nurturance with energy and creativity,

Of knowledge and determination, 
Of passion and hope,

Of remembrance of time past.

They tell me their stories of teaching.

\section{Sebastien Porco}

Seb is an English Language Arts teacher at Chambly Academy. He has a BEd from McGill University.

\section{Perspectives.}

There are two places where my being male is pronounced: The first being Sunday lunch with my all-female paternal cousins, and the second being a high school staffroom. I can't claim this as surprising to me. I have been through high school, and the slim amount of male teachers-specifically English teachers-was rather obvious ... I daresay that my experience as a male English Language Arts teacher has meant being treated like a left-handed relief pitcher, not a commodity or special, but definitely a minority ... My perspective and growth as a male teacher are very similar to those of every teacher ... I went from young adult to full adult in my tenure at the school board, and my perspective has changed with it. I don't believe many of my experiences have been uniquely male, from playing in the intramural dodge ball league, to weekly lunchtime Democracy board games. All of these experiences are not being male, but being a teacher. I look forward to my progression and perspective change, a perspective not limited to my gender, but to my profession.

\section{Denise Schellhase}

Denise teaches History at HRHS. She has a BA from the University of British Columbia, a teaching certificate from Simon Fraser University, and a MA in Education from McGill University.

\section{May 2013.}

I am on a year's maternity leave ... I feel a little bit like [retired Canadian astronaut] Chris Hadfield at the moment. Being away from teaching has shifted my perspective on my role in the educational system. Actually, it hasn't shifted my perspective so much as refocused and cleaned up a pedagogical lens that had gathered some dust over the past 15 years and was in dire need of some handiwork to bring things into sharper view ... I feel as though I am free to dream a little more, to enjoy shapes, and colours, and patterns of the pedagogy that I so strongly believed in when I entered the teaching field. Over the past year, I have really started to embrace and enjoy the 
feeling of being untethered and somewhat weightless. Now, already anticipating a new school year in August, I dread being dragged back down to the gravity of Earth.

\section{October 2013.}

My feeling of weightlessness has been replaced by a dull pressure that inhibits my ability to think of creative solutions and to re-imagine the classroom space...

\section{Kristen Witczak}

Kristen is an English teacher and facilitator of The Professional Conversation Group at Chambly Academy. She has a Bachelor's Degree in Theatre and English from Concordia University and completed her teacher training at OISE/University of Toronto.

\section{Perspective.}

This is a good thing.

Congratulations are in order.

This is what I worked for ...

The gasp said, "The master has freed the slave" ...

I always finish what I start.

I've never abandoned anything that mattered before.

I love those children.

They keep pushing through like hiccups.

I can't imagine life without them.

Who do I give my best to now?

I turned myself into the person they need me to be...

July is a slash wound that won't stop bleeding ...

I wake up one morning and realise

That it's true,

That I was profoundly unhappy,

And couldn't possibly climb out of the grave l'd dug for myself ...

Finally, we have taken individual perspectives from the pieces excerpted above, shared and braided them, again through conversation and consensus. You may recognize ambiguity in our métissage, or it may feel familiar. Perhaps, you will be drawn into the weave with us, and recognize aspects of your experience or self. It is hoped that we will have sparked that note of empathy. 


\section{Perspectives on teaching and learning: A literary métissage.}

I.

All these experiences are not being male,

They are being a teacher.

Work with me for them,

Work with me for us,

Because this is a messy job,

A jigsaw puzzle missing piece after piece after piece.

II.

Some plants need tender care, others I must be harsh with, I will eventually have to separate these shy flowers, It is the weeds that demand the most attention, I love dragonflies, they are my artists and dreamers. I am a good example of how things have changed.

III.

I teach, I learn, I (out)grow, grow into.

I feel very much apart from the work-based discussions, I feel disconnected from the day-to-day bureaucratic mire, All that I hear is noise.

We glance at our watches, we roll through that stop sign, we gulp down one last glug of coffee.

We are all watching for that same sound calling us to teach.

IV.

The light shines around her when learning is valued. I went through school not learning to read or spell, experienced dread, unhappiness, self-loathing. I felt empowered and books became my friend. You will be fine.

Your support changed my world, A day that changed my life and my students' lives too. We all answer to that bell, don't we, Students and teachers alike?

V.

I don't have to do that anymore, I don't have to be there anymore, I don't have to pretend it doesn't bother me anymore. Her passion for learning she chooses to give, This passion for knowledge. I have found my home. 


\section{Interpreting Our Narratives: Driving Deeper Into Oz}

A defining condition of being human is our urgent need to understand and order the meaning of our experience, to integrate it with what we know to avoid the threat of chaos. - Jack Mezirow, Learning as Transformation, 2000, p. 3

The purpose of this paper is to describe the process and the outcome of our journey, however we feel that a brief explanation of our claim to have learned may be necessary. The question guiding this phase of our inquiry is:

- How is the learning of the professional educator evidenced in the narrative inquiry experience, specifically in The Blackboard Monologue productions?

For the purpose of this analysis nine monologues were selected based on the author's availability to participate in a cursory look for evidence of our learning. Our method included coding individually, and as a group, in round-table conversation, in order to attempt to ensure agreement. Each monologue was read aloud and all but the author coded for: a) evidence of experience and b) evidence of learning, which was then shared in discussion. As well, verbatim data chunks supporting interpretations were highlighted, and again, agreement was sought. Finally, experience was further categorized as being either positive or negative and learning as self/cognitive, self/ affective, or as social/in community. While not the primary focus of our inquiry, analysis permitted us to more explicitly understand the learning.

\section{Discussing the Outcomes of Our Learning Thus Far: It's About Brains and Courage and Hearts}

A journey awaits you. It is one filled with possibility and meaning. It will call you to come to know who you are and where you are going. At times you will need to share this pathway, whereas at others, you will travel alone. You will need to make many important choices at crossroads along the way. Each step will carry you to toward new discoveries, so step with great care.

- Karen Whelan, Traveler on a Journey, 1999, p. 20

Dewey, (1938) suggests that, "there is an organic connection between education and personal experience" (p. 12). Therein may lie a fork in the road, a lesson for those 
interested in authentic, meaningful teacher education, but a dead end for those who are not. Within our group we are making that particular connection between education and personal experience, we are making it explicit, and we are making use of it. In our work, we make use of educational research generated within the academy, we make use of reports of practitioner research, and sometimes we make it up as we go. We have the brains. We have the courage. We have the hearts, and we have learned much. This learning is situated in experience, is evidenced across domains, and because we have grown, our intention is to continue. However, the trustworthiness and usefulness of the work of the practitioner-researcher must be established for others. Eisner (1998) posits that "all experience derived from text is transactive, (and) we can ask what it is about text that is likely to make it believable" (p. 53). In our conversations about this, we reference Eisner and ask:

- Does the text make sense (coherence),

- Will those who experience it agree with us (consensus), and

- Is it of use to others (instrumental utility)?

Working with these ideas implies that "we cannot secure an ontologically objective view of the world" (p. 60). Rather, the process of knowing is transactional, and what we know is "mediated by what we bring to the world as we achieve experience ... and what we use to convey our experience" (p. 60). The trustworthiness of the story is key, and may be found in evidence gathered, not just in the story and its background, nor simply from the storyteller, but from our audience as well. "How is the story understood?" becomes the question, and as we take our work forward, we are informed by feedback from others. Part of each presentation or performance is a call for public validation of our work.

\section{Further on Down the Road}

Beyond answers, our research has provided us with questions that we may pursue in the future. We have had to conclude that our professional learning is situated largely in the affective domain, and that spirituality is an issue we wish to explore. Recurring themes of power, and the balancing of the professional and the personal, invite further investigation. Finally, gender, gender orientation, and age are critical frames that require deeper exploration. 


\section{Implications for Teacher Education: See the Ripples in the Grass}

Narratives are a valuable transformative tool. They allow us to see the world in new ways and help us to communicate new ideas to others. We can make worlds in many new ways.

- Sigrun Gudmundsdottir, The Narrative Nature of Pedagogical Content Knowledge

\section{Norma speaks for us all when she writes:}

The act of writing about life and sharing one's own experience is very daunting, but I have learned that through métissage, the sharing and pulling from the writing of a group removes the individual and reveals a depth that resonates the universality of life. In this métissage experience, I discovered that the joy that we receive from the choices we make is greater because we are aware of the possibility of consequences, but are still willing to proceed. (Norma Hubbard, personal communication, March 8, 2014)

However, this is not something learned through her teacher education program. Norma's life and her experience as an inquirer have taught her this. We would like now to offer multiple perspectives on possible implications of our self-directed learning for teacher education.

\section{Perspectives on the Implications for Teacher Education}

\section{Amanda, Seb, and Kristen.}

As early career educators, our experiences with life writing and literary métissage have not only shaped our professional practice, but also largely formed our professional identities and classroom pedagogy.

Our pre-service teacher education emphasized reflecting on experience, but that reflection too easily turned into a forced exercise alone in a classroom, after an isolating, soul-exhausting day of teaching. It began to feel like one more thing on a to-do list instead of an experience that adds value to our practice. The first few years of teaching are notoriously difficult and having a safe space for discussion and learning like The Narrative Inquiry Group, as well as a dedicated time and place to engage in professional conversation, have been elemental in surviving the transition into the life of a professional educator. In The Narrative Inquiry Group, we share perspectives and concerns, and find that we have concerns and experiences similar to those of teachers 
with more experience. Kristen and Martin, for example, experienced similar struggles reconciling their philosophies of art education within a pre-existing school culture, and worked together towards strengthening curriculum delivery in their classrooms.

Through our writing and reflection, we have learned to turn our shared experience into collective knowledge that we then take with us into many aspects of our professional lives. Engaging in life writing within a community of educators transforms reflection on practice into a concrete method of examining our experiences, reflecting on them, sharing with others, and problem-solving for the future, all while fostering a professional community of respect, sharing, and empathy. Participating in this research process has taken the floating, ungrounded theory of our pre-service teacher education and planted it firmly in our quotidian teaching practices.

With regards to classroom practice and pedagogy, our experience within The Narrative Inquiry Group of positioning ourselves as learners has helped us create empathy for our students and their classroom experiences. Just as we find ourselves vulnerable and challenged, so too, do students. In bringing methodologies from The Narrative Inquiry Group to our classrooms, we and our students have learned together, becoming collective owners of what we have learned, and having shared responsibility for what we are contributing. As the newcomers to $\mathrm{Oz}$, the Dorothys caught up in the cyclone and deposited in lands unfamiliar, early-career educators often find themselves seeking safety and familiarity. We are often lost, but within our newfound community of hearts, brains, and courage, we create for ourselves a new home.

\section{Norma and Martin.}

As mid-career teachers, we are quite aware of the established culture, the Flying Monkeys of our school, who often try to scare us into a singular direction regarding the how-to and what-to in the teaching of the arts and literature. However, we have spent enough hours in our classrooms to create our own Emerald Cites, small micro-worlds against the outside world. While to others on the outside it may appear impressive, within our classrooms, our Emerald Cities, there can be problems. We may take control as we close our doors on those annoying Flying Monkeys, but we are isolating ourselves. We wonder if we are alone in our experiences, or do others have similar problems. We question, "Is it just me?"

The Narrative Inquiry Group provides a forum to focus on our strengths, our values in the arts and literature. We are able to discuss ideas with others. We ask, "What is art education?" Within the safe environment of the group, we become more confident of our values. We explore the expectations of art in the public, versus the real beauty 
of art inside each of our students. We come to understand that in order for the students to produce authentic writing, they must examine more than the prescribed curriculum. And so, we give our students the tools that will move them from a surface understanding to a deeper knowledge that will empower them to contribute to their own educational improvement.

Over time there may be a point where we become too comfortable within our classrooms, much like Dorothy and others who could have remained in the Emerald City. That was not enough for any of them, nor should it be for us. We need opportunities to share ideas so that we don't become complacent in our teaching. We need to take multiple, alternate perspectives in order to give our best to our students. The Narrative Group provides such a forum. With our stories we encourage, critique, and challenge one another. Our writing connects us to our inside worlds, our deeper thoughts, our sensitivities, and our emotions. We become better educators.

\section{Mary, Laurie, and Judy.}

We are among the most experienced of the members of our group, and over time we have come to understand that it is not enough to rely on pre-service learning. It is not enough to depend solely on practical knowledge constructed in the field. It is not enough to learn about theory without an understanding of the research behind it and the applications that ought to follow in practice. With experience, we have come to value lifelong learning.

The teacher educator has a valued and respected relationship with practitioners, and particularly, with those entering the profession. With an appreciation of the role of the teacher educator, and an understanding of the worth of the practical knowledge and wisdom of the teacher in the field, conversation across contexts becomes possible. To begin the conversation we would like to suggest that a teacher education program:

- Create a context in which risk-taking that facilitates professional efficacy and growth is encouraged; a context that ensures opportunities for reflection and critical dialogue, and

- Give teachers the tools to learn about theory, research, and practice at a deep and meaningful level, in formal, non-formal and informal settings, throughout their careers; tools that will empower them to inquire and to make a contribution to improved pedagogy and cultural change. 
While we may wish that the teacher educator possess all of the assumed powers of the Wizard of $\mathrm{Oz}$, and that teachers wear ruby slippers, we realize that this is not the case. We have discovered in our collaborations across the years and various contexts, that new and experienced educators gain confidence in their knowledge and abilities through reflection, professional conversation, and inquiry. We understand that the power needed to support the evolution of teaching practices and learning outcomes in our schools is fuelled by career-long, embedded professional development.

\section{An Invitation to Professional Conversation}

I hold the view that educational theory is a form of dialogue which has profound implications for the future of humanity because of the values it holds and because it is embodied in our practical lives in our workplaces and wider society.

- Jack Whitehead, The Growth of Educational Knowledge (1993, p. 6)

How is learning from reflection on experience evidenced in our products as we engage in narrative inquiry? Gary Hoban (2002) offers this: "The action of reflection ... is the rethinking of experience provid(ing) personal meaning and hence learning" (p. 53). As we learn, we construct a shared understanding of the complexities of the contexts, processes, experiences, and surprises of teaching and learning, of life and work. We attempt to make things better, and we are finding our way with this. The greatest benefit of literary métissage is the development of empathetic hearts of wisdom (Chambers et al., 2012). In such relationships, educators survive the tensions and the contrasts between the possibilities and realities of life in schools. As narrators, we describe our life experiences via storytelling, capturing and braiding our voices, while inviting others into the braid and to an understanding of the implications. We believe that dialogue across educational communities creates the possibility for institutional change, change that may have a greater social impact than conversations occurring in isolation. We envision a bridge across institutions embodying shared values.

Our methods may seem somewhat "controversial in the academy, blurring traditional methods of dissemination in an effort to better communicate the educational significance" (Sinner, 2013, p. 2). Nevertheless, our products provide documentation of the process of critical reflection, of transformed meaning perspectives, of direction for change. Learning occurs through the explication, elaboration, and transformation of existing perspectives as a consequence of critical reflection (Mezirow, 2000). We are sharing the outcomes of our reflective insights as we move forward, and we welcome others on our journey. Institutional transformation is ours to make, teachers and teacher educators working together. Like Dorothy and her companions on the road, we have had the power all along. 


\section{References}

Baum, F.L. (1939). The wonderful wizard of Oz. New York: Dover.

Chambers, C.M., Hasebe-Ludt, E., Leggo, C., \& Sinner, A. (2012). A heart of wisdom: Life writing as empathetic inquiry. New York: Peter Lang.

Clandinin, D.J., \& Connelly, F.M. (2000). Narrative inquiry: Experience and story in qualitative research. San Francisco: Jossey-Bass.

Dewey, J. (1933). How we think: A restatement of reflective thinking to the educative process. Boston: Heath.

Dewey, J. (1938/1998). Experience and education. Indianapolis, IN: Kappa Delta Pi.

Duff, P.A. (2002). Narrative inquiry: More than just telling stories. TESOL Quarterly, 26(2), 207-213.

Eisner, E. (1998). The enlightened eye: Qualitative inquiry and the enhancement of educational practice. Upper Saddle River, NJ: Prentice Hall.

Elza, D. (2011). It's like telling people you have rats and forgetting to qualify them as pets: A poet's journey. LEARNing Landscapes, 4(2), 187-194.

Ensler, E. (2001). The vagina monologues. New York: Villard Books.

Gudmunsdottir, S. (1995). The narrative nature of pedagogical content knowledge. In H. McEwan \& K. Egan (Eds.), Narrative in teaching, learning, and research. New York: Teachers College Press.

Hamdan, S. (2013). Happy am I. Holy am I. Healthy am I. Sharp Thinking Communications.

Hasebe-Ludt, E., Chambers, C., \& Leggo, C. (2009). Life writing and literary métissage as an ethos for our times. New York: Peter Lang.

Hoban, G. (2002). Teacher learning for educational change. Philadelphia: Open University Press.

Holly, M., Arhar, J., \& Kasten, W. (2001). Research for teachers: Traveling the yellow brick road. Upper Saddle River, NJ: Merrill Prentice Hall.
Hubbard, N., Jager, A., Labrie, M., MacLeod, M., Mallet, D., McBride, J. et al. (2013). The blackboard monologues: Perspectives on the personal and the professional lives of educators. Paper presented at the Annual Convention of the Quebec Provincial Association of Teachers. November 21, 2013, Montreal, QC, Canada.

Irvine, S., \& Collie, M. (2011). The professional conversation: A new approach to professional learning in early childhood education and care. Retrieved from: http://eprints.qut. edu.au/47714/

Jager, A., Hubbard, N., Labrie, M., MacLeod, L., Mallet, D., McBride, J. et al. (2014). Situating the practitioner's learning in the gap between theory and practice. Paper presented to the Annual Conference of the Education Graduate Students' Society, Faculty of Education, McGill University, Montreal, Quebec.

Kamanzi, P., Riopel, M., \& Lessard, C. (2007). School teachers in Canada: Context, profile and work - highlights of a pan Canadian survey. Retrieved from: https://depot.erudit. org/bitstream/003042dd/1/Hightlights $\% 20$ of $\% 20 a \% 20$ pancanadian $\% 20$ survey.pdf

Leggo, C. (2010). Writing a life: Representation in language and image. Transnational Curriculum Inquiry, 7(2), 47-61.

Mezirow, J. (1991a). Fostering critical reflection in adulthood. San Francisco: Jossey-Bass.

Mezirow. J. (1991b). Transformative dimensions of adult learning. San Francisco: Jossey-Bass.

Mezirow, J. (2000). Learning as transformation: Critical perspectives on a theory in progress. San Francisco: Jossey-Bass.

Naylor, C., O'Neill, E., \& Rojem, K. (n.d.). Teacher worklife research. Vancouver, BC: British Columbia Teachers Federation. Retrieved from: https://www.bctf.ca/Issues InEducation.aspx?id=21453\&libID $=21443$

Rust, F. O. (2002). Teacher research and the problem of practice. Teachers College Record, 111(8), 1882-1893. 
Simpkins, S. (2012). Narrative métissage: Crafting empathy and understanding of self/other. (Unpublished doctoral dissertation). University of Victoria, Victoria, BC.

Sinner, A. (2010). Fragments: Spectres of a sojourning sojourner. Transnational Curriculum Inquiry, 7(2), 75-81.
Sinner, A. (2013). Unfolding the unexpectedness of uncertainty: Creative non-fiction and the lives of becoming teachers. Boston: Sense.

Whitehead, J. (1993). The growth of educational knowledge: Creating your own living educational theories. Bournemouth: Hyde.

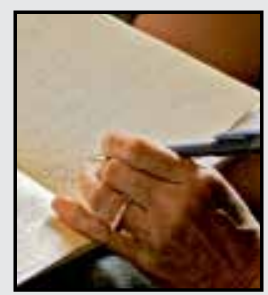

The Narrative Inquiry Group is a writers' collective with 11 members. Our group is composed of teachers and nonteaching professionals, active and retired, from three public secondary schools in Quebec, Canada. We meet every few weeks to talk, reflect, write, analyze, illustrate, and braid lived experience through life writing. As well, we seek opportunities to perform the products of our professional conversations and to engage with others in the practice of narrative inquiry and literary métissage. 